\title{
Preferences for Attributes of Medications among Patients with Type 2 Diabetes: A Cross-Medication Class Comparison of Injection Therapies
}

\author{
Jiat Ling Poon ${ }^{1 *}$, Kristina S Boye ${ }^{1}$, Vivian T Thieu ${ }^{1}$, Kirsi Norrbacka ${ }^{2}$, Syed W Hassan ${ }^{3}$ and Heather L Gelhorn ${ }^{4}$ \\ ${ }^{1}$ Eli Lilly and Company, USA \\ ${ }^{2}$ Eli Lilly Finland, Finland \\ ${ }^{3}$ Eli Lilly and Company, UK \\ ${ }^{4}$ Evidera, Bethesda, USA \\ Submission: February 12, 2018; Published: April 16, 2018 \\ *Corresponding author: Jiat Ling Poon, Patient-Focused Outcomes Center of Expertise, Global Patient Outcomes and Real World Evidence, Eli \\ Lilly and Company, Lilly Corporate Center, Indianapolis, IN 46285, USA, Tel: +1 317 4197497; Email: poon_jiat_ling@lilly.com
}

\begin{abstract}
Purpose: To use a discrete choice experiment (DCE) to determine patient preferences for the treatment features of dulaglutide $1.5 \mathrm{mg}$ vs insulin glargine (SoloSTAR $囚$ ) among people with type 2 diabetes mellitus (T2DM) naïve to injectable diabetes therapy, in the United Kingdom (UK).

Methods: In-person interviews were conducted among people in the UK with self-reported T2DM, naïve to treatment with injectable diabetes medications. The DCE examined seven treatment attributes each described by two levels: frequency of gastrointestinal side effects, frequency of hypoglycemia, frequency of pancreatitis, dosing frequency, HbA1c change, weight change and type of delivery system. Attribute selection was informed by qualitative interviews with people with T2DM treated with oral and/or injectable medications. Part-worth utilities were estimated using random effects logit models and used to calculate relative importance (RI) values for each attribute. Chi-square test was used to determine differences in preferences for dulaglutide vs insulin glargine profiles.
\end{abstract}

Results: 232 participants completed the study [mean \pm SD: age $61.8 \pm 10.8$ years; BMI $29.8 \pm 6.1 \mathrm{~kg} / \mathrm{m}^{2} ; 74.1 \%$ male]. RI of attributes in rank order were: type of delivery system (19.8\%), frequency of gastrointestinal side effects (18.2\%), dosing frequency (17.7\%), weight change (15.6\%), HbA1c change (14.2\%), frequency of pancreatitis $(12.3 \%)$ and frequency of hypoglycemia $(2.2 \%)$. The majority of participants preferred the dulaglutide profile $(75.0 \%)$ compared to the insulin glargine profile $(25.0 \%)(\mathrm{p}<0.01)$. There were differences in preferences for weight changes between males and females, and dosing frequency between those aged $<60$ and aged $\geq 60$ years.

Conclusion: Of the attributes tested, no one attribute highly drove patients' preferences. The majority of participants preferred the dulaglutide profile over the insulin glargine (SoloSTAR $®$ ) profile. The results will help treatment providers understand the clinical and nonclinical factors influencing preferences of people with T2DM, naïve to injectable diabetes medications, when considering next treatment options.

Keywords: Type 2 diabetes; Preference; Discrete choice experiment; Insulin; GLP-1 receptor agonist

Abbreviations: ADA: American Diabetes Association; DCE: Discrete Choice Experiment; EASD: European Association for the Study of Diabetes; GLP-1 RA: Glucagon-like Peptide-1 Receptor Agonists; HbA1c: Glycated Hemoglobin; RI: Relative Importance; SD: Standard Deviation; T2DM: Type 2 Diabetes Mellitus; UK: United Kingdom.

\section{Introduction}

The American Diabetes Association's (ADA) 2017 update to standards of diabetes care has recommended the use of metformin as first-line therapy in addition to lifestyle management, with second-line therapy selected based on patient-specific considerations [1]. These patient-specific considerations may include efficacy, risk of hypoglycemia, impact on weight, side effects, costs, renal effects, and patient preferences [2]. Secondline dual therapy recommends the addition of a second oral

agent or an injectable agent to existing metformin and lifestyle management. Recommended injectable agents are glucagon-like peptide-1 receptor agonists (GLP-1 RA) or basal insulin [1]. GLP1 RAs have proven efficacy in lowering $\mathrm{HbA1c}$ while reducing weight, some cardiovascular risk factors, and postprandial glucose excursions, and minimizing risk of hypoglycemia; disadvantages of GLP-1 RAs include gastrointestinal side effects, increased heart rate, and potentially acute pancreatitis [1]. Basal 
insulin with longer-acting basal insulin analogues also have proven efficacy in managing blood glucose levels; disadvantages of insulin include hypoglycemia and weight gain [1].

As recommended by the ADA and the European Association for the Study of Diabetes (EASD) [2], it is important to understand patient-specific factors that may affect treatment selection, including patient preferences. Several studies have examined medication preferences among people with type 2 diabetes. These have generally compared generic features of diabetes treatments across dosage forms [3], compared patient preferences for features for oral anti-diabetic treatments [46], or compared patient preferences for features of GLP-1 RA treatments [7-10]. To date, however, no known published DCEs have examined patients' preferences for specific features across different classes of injectable diabetes treatments, specifically, comparing GLP-1 RAs and basal insulin.

The objective of this study was to use a DCE to evaluate patients' preferences for the treatment features, efficacy, and side effects of dulaglutide $1.5 \mathrm{mg}$ versus insulin glargine among people with type 2 diabetes in the UK. A secondary objective was to determine direct patient preferences for the profiles of dulaglutide $1.5 \mathrm{mg}$ versus insulin glargine, with additional exploratory objective to determine patients' willingness to self-inject medication for the treatment of type 2 diabetes.

\section{Methods}

\section{DCE design}

Attributes included in the study were selected based on: (1) a literature review of attributes commonly included in other DCEs for T2DM medications, which were relevant to a comparison of GLP-1 RAs and insulin glargine, and (2) results from one-on-one in-person qualitative interviews conducted with 15 people with T2DM in the UK, receiving treatment with oral and/or injectable medications. In the qualitative interviews, participants were asked to identify key concerns regarding treatment for diabetes and in particular, injectable treatment options and outcomes, which were relevant for influencing their treatment decisions. Patients with experience using injectable diabetes treatments were included in the qualitative interviews in order to capture concepts relevant to diabetes management with injectable therapies that cannot be elicited from patients naïve to injectable therapies.

Based on this prior work, seven attributes were selected for inclusion in the DCE study design (Table 1). These were: (1) frequency of gastrointestinal side effects, (2) frequency of low blood sugar (hypoglycemia), (3) frequency of pancreatitis, (4) dosing frequency, (5) blood sugar (HbA1c) change, (6) weight change, and (7) type of delivery system. These attributes comprise those which are consistently reported to be of high importance to patients (i.e., hypoglycemia, dosing frequency, blood sugar change, weight change), and also some that serve to differentiate GLP-1 RAs and insulin glargine. Cost was not included as an attribute, as it is not as relevant in single payer systems such as the UK. Levels for each included attribute were based on the results of a head-to-head clinical trial (AWARD-2), which compared dulaglutide and insulin glargine [11], as well as official instructions to use dulaglutide and insulin glargine devices $[12,13]$. The attributes and associated levels were subsequently tested in a pilot study to ensure participant comprehension of the descriptions and DCE task prior to conducting the full study. It is also key to note that insulin glargine can be delivered through different devices. The SoloSTAR $®$ device was presented to participants in this study because it was the specific device used in AWARD-2, which formed the basis of the attributes and levels.

Sample size was estimated using the number of choice pairs (12) included in the DCE, number of alternatives (two) per choice pair, and maximum number of levels (two) for any one attribute. Based on these parameters, a minimum sample size of 200 participants was targeted.

\section{Participants}

Participants were recruited via newspaper and magazine advertisements in four UK locations: London, Birmingham, Cardiff, and Edinburgh. Interested participants were screened via telephone to assess eligibility. To be eligible, participants had to be: $\geq 18$ years of age; a current resident of the UK; diagnosed with T2DM; currently treated for T2DM with oral medications only; able to read and understand English; able and willing to travel to the interview location; and willing and able to provide informed consent. Participants were excluded if they had type 1 diabetes or current gestational diabetes; T2DM currently treated only with diet and exercise; or had previously received regular treatment with injectable medication for T2DM. In order to confirm their T2DM diagnosis, participants were required to bring their T2DM prescription medication to the interview. All participants provided informed consent prior to participating in the study and the study protocol was approved by an independent ethical review board (Ethical \& Independent Review Services; Study number 16100-01; Approved August 21, 2016).

\section{Study Procedures}

The study consisted of a pilot (London: August-September 2016) and a main study (London, Birmingham, Cardiff, and Edinburgh: October 2016-January 2017). The purpose of the pilot was to assess participant comprehension of study descriptions, relevance of study attributes to their T2DM, and burden of completing the study questionnaires. Surveys were administered in person by trained moderators, though participants self-completed the survey questions on paper. Following completion of study procedures, participants were remunerated to cover their time and travel expenses.

The study consisted of five parts: (1) a question determining participants' willingness to self-inject medication for T2DM; (2) a written description of the purpose of the DCE and the 
medication attributes and levels; (3) the DCE choice tasks; (4) supplementary questions asking about participants' willingness to self-inject products with profiles representing dulaglutide and insulin glargine (SoloSTAR $囚$ ); and (5) a sociodemographic and clinical information questionnaire.

Prior to completing the DCE, participants read a brief description of the purpose of the study and reviewed the list of seven included attributes and their possible levels (Table 1). Participants were instructed that they would be presented with pairs of hypothetical medication profiles and for each pair would

Table 1: Attributes and levels.

\begin{tabular}{|c|c|c|}
\hline Attribute & Description & Options for Levels \\
\hline $\begin{array}{l}\text { Frequency of } \\
\text { Gastrointestinal } \\
\text { Side Effects }\end{array}$ & $\begin{array}{c}\text { The most common side effects are } \\
\text { gastrointestinal symptoms, including } \\
\text { nausea (feeling sick but NOT vomiting), } \\
\text { vomiting, or diarrhea. } \\
\text { of these, nausea is most commonly } \\
\text { experienced. }\end{array}$ & 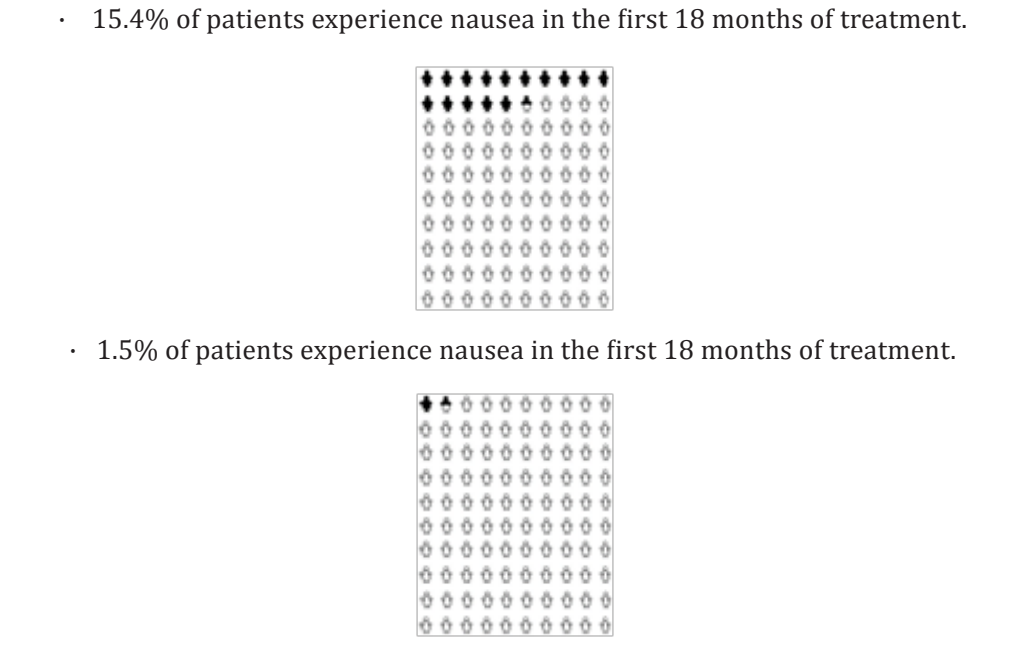 \\
\hline $\begin{array}{l}\text { Frequency of } \\
\text { Low Blood } \\
\text { Sugar Event } \\
\text { (Hypoglycemia) }\end{array}$ & $\begin{array}{l}\text { Number of low blood sugar events } \\
\text { (hypoglycemia) that patients may } \\
\text { experience with use in } 12 \text { months. } \\
\text { Low blood sugar events can result in a } \\
\text { range of symptoms, including dizziness } \\
\text { and shakiness. }\end{array}$ & $\begin{array}{l}\text { - On average, patients experience approximately } 5 \text { events of low blood sugar in the } \\
\text { first } 12 \text { months of treatment. } \\
\text { - On average, patients experience approximately } 8 \text { events of low blood sugar in } 12 \\
\text { months of treatment. }\end{array}$ \\
\hline $\begin{array}{l}\text { Frequency of } \\
\text { Pancreatitis } \\
\text { (inflammation } \\
\text { of the pancreas) }\end{array}$ & $\begin{array}{l}\text { The likelihood that the medication will } \\
\text { cause an inflammation of the pancreas. } \\
\text { Pancreatitis is the inflammation of } \\
\text { the pancreas; it may cause severe } \\
\text { abdominal pain and in some cases } \\
\text { require hospitalizations. }\end{array}$ & 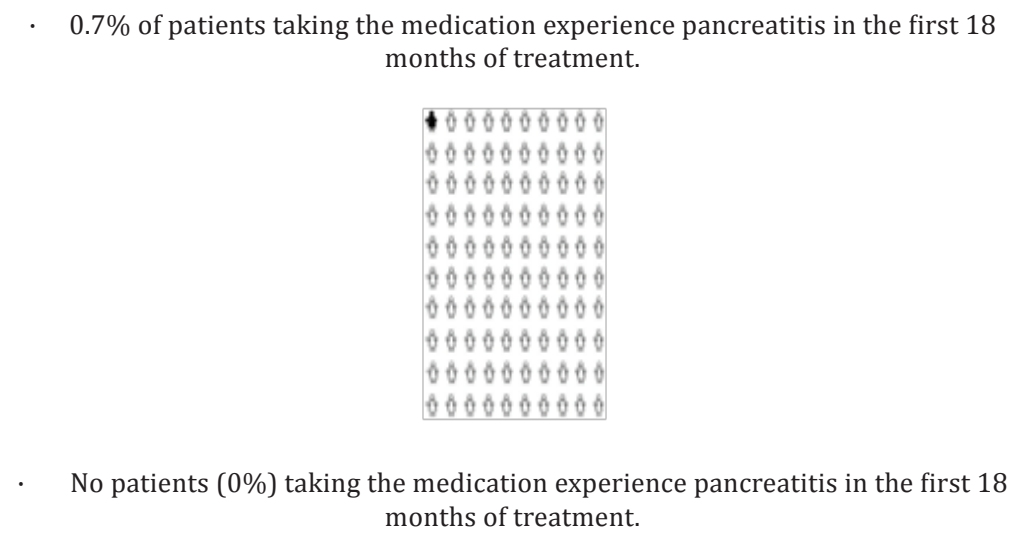 \\
\hline $\begin{array}{l}\text { Dosing } \\
\text { Frequency }\end{array}$ & $\begin{array}{l}\text { How often patients have to take the } \\
\text { medication. }\end{array}$ & $\begin{array}{l}\text { - Once a week (52 times per year) } \\
\text {. Once a day (365 times per year) }\end{array}$ \\
\hline
\end{tabular}

be asked to select the profile they preferred. Each medication was composed of one level from each of the seven attributes. Participants completed 14 DCE questions. Prior to completing the DCE choice tasks, participants also watched two brief videos describing the use of the dulaglutide and insulin glargine (SoloSTAR $囚$ ) injection devices, which were based upon product Instructions for Use materials. The order of presentation of these videos was varied by using a block design. No product names were mentioned in either the videos or the questionnaires, nor were patients informed that the product was either a GLP-1 RA or an insulin product. 


\section{Current Research in Diabetes \& Obesity Journal}

\begin{tabular}{|c|c|c|}
\hline $\begin{array}{l}\text { Blood Sugar } \\
\text { (HbA1c) } \\
\text { Change }\end{array}$ & $\begin{array}{c}\text { Likelihood that the patient will reach } \\
\text { the blood sugar target of an HbA1c less } \\
\text { than } 7 \% \text { within the first } 12 \text { months of } \\
\text { use. }\end{array}$ & $\begin{array}{l}\text { 53.2\% of patients taking the medication reach their target blood sugar (HbA1c) } \\
\text { goals of less than } 7 \% \text { within the first } 12 \text { months of treatment. } \\
\text { 30.9\% of patients taking the medication reach their desired blood sugar (HbA1c) } \\
\text { goals of less than } 7 \% \text { within the first } 12 \text { months of treatment. } \\
+\$+\$+\$+\$ \\
+\$+\$+\$+\$+\$+\$ \\
+000000000 \\
0000000000 \\
0000000000 \\
0000000000 \\
0000000000 \\
0000000000 \\
0000000000\end{array}$ \\
\hline Weight Change & $\begin{array}{l}\text { Medication-related weight changes } \\
\text { that patients will experience within the } \\
\text { first } 12 \text { months of use. }\end{array}$ & $\begin{array}{l}\text { On average, patients experience a weight loss of }-1.87 \mathrm{~kg} \text { within the first } 12 \\
\text { months of treatment. } \\
\text { On average, patients experience a weight gain of }+1.44 \mathrm{~kg} \text { within the first } 12 \\
\text { months of treatment. }\end{array}$ \\
\hline $\begin{array}{c}\text { Type of } \\
\text { Delivery System }\end{array}$ & $\begin{array}{l}\text { The device and procedure used to } \\
\text { inject the medication }\end{array}$ & 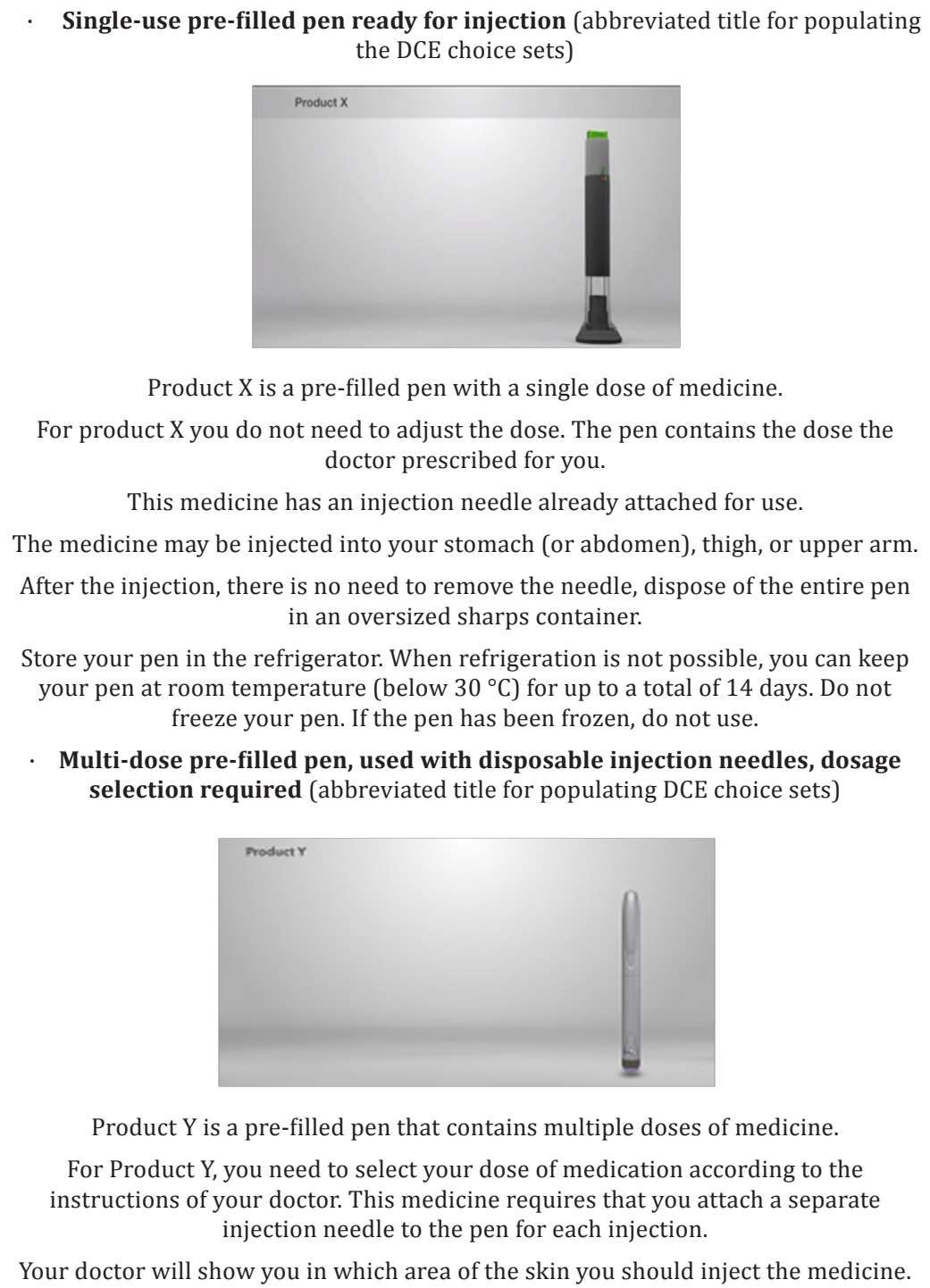 \\
\hline
\end{tabular}




\section{Current Research in Diabetes \& Obesity Journal}

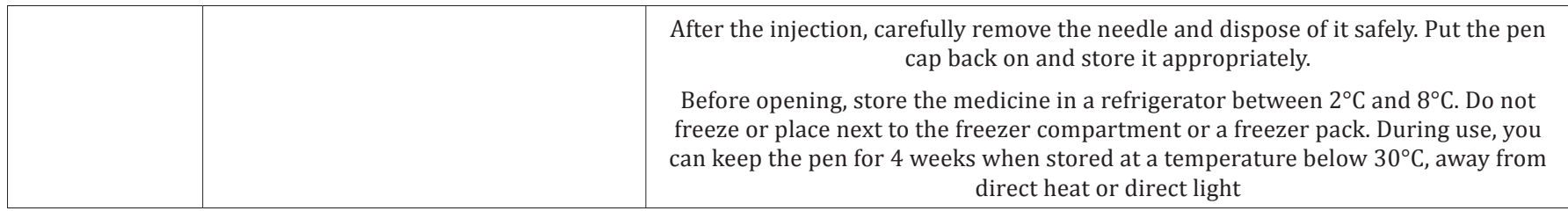

HbA1c: Glycated Hemoglobin

10. Which of these two treatment options do you prefer? (Please place a tick in one box to make your selection)

\begin{tabular}{|c|c|c|c|c|}
\hline & \multicolumn{2}{|c|}{ Option A } & \multicolumn{2}{|c|}{ Option B } \\
\hline $\begin{array}{l}\text { Frequency of } \\
\text { Gastrointestinal } \\
\text { Side Effects }\end{array}$ & $\begin{array}{c}15.4 \% \\
\text { experience nausea } \\
\text { in the first } 18 \text { months } \\
\text { of treatment }\end{array}$ & 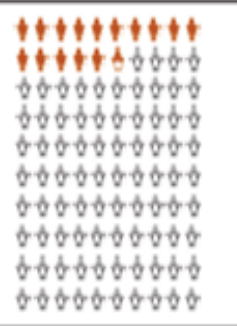 & $\begin{array}{c}1.5 \% \\
\text { experience nausea } \\
\text { in the first } 18 \text { months } \\
\text { of treatment }\end{array}$ & 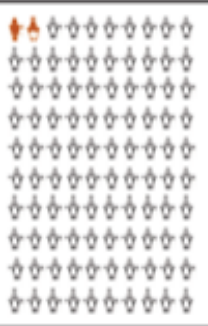 \\
\hline $\begin{array}{l}\text { Frequency of Low } \\
\text { Blood Sugar Event } \\
\text { (Hypoglycaemia) }\end{array}$ & \multicolumn{2}{|c|}{$\begin{array}{l}\text { Average of approximately } 5 \text { events of } \\
\text { low blood sugar in the first } 12 \text { months of } \\
\text { treatment }\end{array}$} & \multicolumn{2}{|c|}{$\begin{array}{l}\text { Average of approximately } 8 \text { events of } \\
\text { low blood sugar in the first } 12 \text { months of } \\
\text { treatment }\end{array}$} \\
\hline $\begin{array}{l}\text { Frequency of } \\
\text { Pancreatitis } \\
\text { (inflammation of the } \\
\text { pancreas) }\end{array}$ & $\begin{array}{l}0.7 \% \\
\text { experience } \\
\text { pancreatitis in the } \\
\text { first } 18 \text { months of } \\
\text { treatment }\end{array}$ & 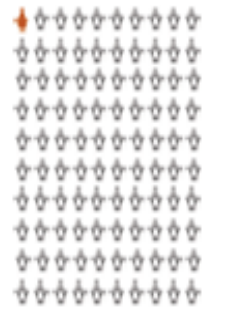 & $\begin{array}{l}\text { No patients } \\
\text { experience } \\
\text { pancreatitis in the } \\
\text { first } 18 \text { months of } \\
\text { treatment }\end{array}$ & 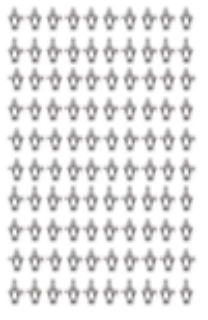 \\
\hline Dosing Frequency & \multicolumn{2}{|c|}{ Once a week (52 times per year) } & \multicolumn{2}{|c|}{ Once a day ( 365 times per year) } \\
\hline $\begin{array}{l}\text { Blood Sugar } \\
\text { (HbA1c) Change }\end{array}$ & $\begin{array}{c}53.2 \% \\
\text { reach desired blood } \\
\text { sugar (HbA1c) goals } \\
\text { of less than } 7 \% \\
\text { within the first } 12 \\
\text { months of treatment }\end{array}$ & 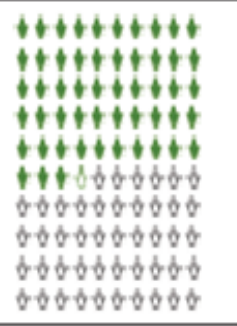 & $\begin{array}{c}30.9 \% \\
\text { reach desired blood } \\
\text { sugar (HbA1c) goals } \\
\text { of less than } 7 \% \\
\text { within the first } 12 \\
\text { months of treatment }\end{array}$ & 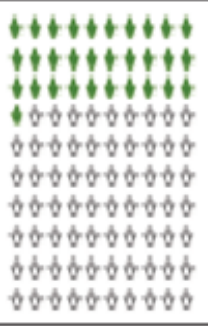 \\
\hline Weight Change & \multicolumn{2}{|c|}{$\begin{array}{l}-1.87 \mathrm{~kg} \text { weight loss } \\
\text { within first } 12 \text { months of } \\
\text { treatment }\end{array}$} & \multicolumn{2}{|c|}{$\begin{array}{l}+1.44 \mathbf{~ k g} \text { weight gain } \\
\text { within first } 12 \text { months of } \\
\text { treatment }\end{array}$} \\
\hline \multirow[t]{2}{*}{$\begin{array}{l}\text { Type of Delivery } \\
\text { System }\end{array}$} & \multicolumn{2}{|c|}{$\begin{array}{l}\text { Single-use pre-filled pen } \\
\text { ready for injection }\end{array}$} & \multicolumn{2}{|c|}{$\begin{array}{l}\text { Multi-dose pre-filled pen, used with } \\
\text { disposable injection needles, dosage } \\
\text { selection required }\end{array}$} \\
\hline & $\operatorname{man} x$ & & nowar & \pm \\
\hline $\begin{array}{l}\text { If I had to choose } \\
\text { one option, I would } \\
\text { prefer: }\end{array}$ & & & & \\
\hline
\end{tabular}

Figure 1: Medication profile comparison 


\section{Current Research in Diabetes \& Obesity Journal}

One of the DCE questions presented was a fixed choice question with a clearly correct medication option; this question was used as a validity check to ensure that participants understood the task and were attending appropriately to the medication choices. Prior to data analysis, any participants who responded incorrectly to the test medication choice were removed from the analysis set. A second DCE question presented participants with two medication choices, each representing the characteristics of dulaglutide and insulin glargine (SoloSTAR $®$ ), and was used to determine participants' direct preference for profiles representing the two medications (Figure 1). Both these questions were embedded within the DCE design and were indistinguishable to participants from the other DCE questions. The responses to both these questions were not included in the estimation of preference weights.

Participants first completed a supplementary question to elicit their willingness to self-inject diabetes medication. After the DCE, participants completed two additional questions to determine their willingness to self-inject medication with the profile representing dulaglutide and insulin glargine (SoloSTAR®), separately. Participants then completed a sociodemographic and clinical characteristics questionnaire, which included age, gender, living situation, employment, education level, racial/ethnic background, and questions related to participants' T2DM history.

\section{Analyses}

A priori, the decision was made to pool data from the pilot and main study for analysis if there were no substantive changes to the experimental design. Descriptive statistics (frequencies, means, and standard deviations [SD]) were used to describe participant sociodemographic and self-reported clinical characteristics, and summarize supplementary variables on willingness to use injectable medications and willingness to use medications represented by the dulaglutide and insulin glargine (SoloSTAR®) profiles.

DCE responses were analyzed using a logit regression model to estimate part-worth utilities [9] for the overall sample, and by age, sex, and duration of diabetes subgroups. Part-worth utility values, or preference weights, provide information on the extent to which participants prefer each level of an attribute, and are scaled within each attribute to have a mean of zero. A positive part-worth utility value indicates that the attribute level is preferred over levels with negative values. Larger part-worth utility values indicate a higher degree of preference for one level over another.

The relative importance (RI) of each attribute is expressed as a percentage and reflects the proportion of the variance in the overall medication decision that is accounted for by each attribute. RI was calculated by summing the range of part-worth utility values (ie, the largest minus the smallest part-worth utility values within each attribute) for all attributes yielding the overall utility value, and then by dividing each individual attribute's utility range by the overall utility value [14]. Chisquare tests were used to determine whether there were significant differences in the RI of attributes across subgroups. The fixed choice question and the question comparing the dulaglutide and insulin glargine (SoloSTAR $\AA$ ) profiles were not included in the DCE analysis. All analyses were conducted using SAS Version 9.4 (SAS Institute Inc.).

\section{Results}

\section{Sample characteristics}

Overall from both the pilot and main studies, 382 participants were screened, 277 were eligible, and 237 successfully consented and completed the study. Of these, five were removed from the sample due to incorrect responses to the fixed choice question $(n=4)$ or straight-lining of responses $(n=1)$. The final pooled analytical sample consisted of 232 participants who completed the survey and passed the validity check.

The demographic and self-reported clinical characteristics of the participants are presented in Table 2. Mean age of participants was $61.8(\mathrm{SD}=10.8)$ years, and the majority were male $(n=172,74.1 \%)$, and White $(n=181,78 \%)$; almost half of the sample was retired $(n=113,48.7 \%)$. There was an approximately even distribution of participants by educational level and household income. Mean body mass index was $29.8 \mathrm{~kg} /$ $\mathrm{m}^{2}(\mathrm{SD}=6.1)$. Many participants $(\mathrm{n}=85 ; 36.6 \%)$ had had T2DM for between 1 to 5 years, and 67 (28.9\%) and 63 (27.2\%) had had T2DM for between 5-10 years, or more than 10 years, respectively. Most participants were currently taking one oral diabetes medication $(\mathrm{n}=111 ; 47.8 \%)$, and approximately onethird reported a current HbA1c level below 7\% ( $n=71,30.6 \%)$, though approximately one-third were not aware of their current HbA1c levels $(n=70,30.2 \%)$

Table 2: Demographics and self-reported clinical characteristics.

\begin{tabular}{|c|c|}
\hline & \multicolumn{2}{|c|}{ Overall Sample N=232 } \\
\hline \multicolumn{2}{|c|}{ Gender } \\
\hline Male & $172(74.1 \%)$ \\
\hline Female & $60(25.9 \%)$ \\
\hline Age (years), Mean (SD), [Range] & \multicolumn{1}{|c|}{ Race/Ethnicity $(10.8)[27-87]$} \\
\hline White & $181(78.0 \%)$ \\
\hline Asian or Asian-British & $32(13.8 \%)$ \\
\hline
\end{tabular}




\section{Current Research in Diabetes \& Obesity Journal}

\begin{tabular}{|c|c|}
\hline Black/African/Caribbean/Black British & $15(6.5 \%)$ \\
\hline Mixed/Multiple Ethnic Groups & $3(1.3 \%)$ \\
\hline Other & $0(0.0 \%)$ \\
\hline Missing & $1(0.4 \%)$ \\
\hline \multicolumn{2}{|c|}{ Employment status } \\
\hline Full-time & $48(20.7 \%)$ \\
\hline Part-time & $26(11.2 \%)$ \\
\hline Homemaker/Housewife & $3(1.3 \%)$ \\
\hline Student & $2(0.9 \%)$ \\
\hline Unemployed & $23(9.9 \%)$ \\
\hline Retired & $113(48.7 \%)$ \\
\hline Disabled & $6(2.6 \%)$ \\
\hline Other & $10(4.3 \%)$ \\
\hline Missing & $1(0.4 \%)$ \\
\hline \multicolumn{2}{|c|}{ Education } \\
\hline No formal qualifications & $21(9.1 \%)$ \\
\hline GCSE/ 'O' levels or equivalent & $41(17.7 \%)$ \\
\hline 'A' levels or equivalent & $34(14.7 \%)$ \\
\hline Vocational/work based qualifications & $45(19.4 \%)$ \\
\hline University degree & $43(18.5 \%)$ \\
\hline Post-graduate degree & $32(13.8 \%)$ \\
\hline Other & $16(6.9 \%)$ \\
\hline \multicolumn{2}{|c|}{ Household income } \\
\hline Less than $€ 5,200$ & $11(4.7 \%)$ \\
\hline$£ 5,200$ to $£ 10,399$ & $20(8.6 \%)$ \\
\hline$£ 10,400$ to $£ 15,599$ & $32(13.8 \%)$ \\
\hline$£ 15,600$ to $£ 20,799$ & $23(9.9 \%)$ \\
\hline$£ 20,800$ to $£ 25,999$ & $19(8.2 \%)$ \\
\hline$£ 26,000$ to $£ 31,199$ & $26(11.2 \%)$ \\
\hline$£ 31,200$ to $£ 36,399$ & $22(9.5 \%)$ \\
\hline$£ 36,400$ to $£ 51,999$ & $22(9.5 \%)$ \\
\hline$£ 52,000$ or more & $20(8.6 \%)$ \\
\hline Did not answer & $37(15.9 \%)$ \\
\hline Height (Centimeters), Mean (SD) [Range] & $172.5(9.7)[137-193]$ \\
\hline Weight (kg), Mean (SD) [Range] & $89.0(20.6)[51-191]$ \\
\hline BMI $^{\mathrm{a}}\left(\mathrm{kg} / \mathrm{m}^{2}\right)$, Mean (SD) [Range] & $29.8(6.1)[20-67]$ \\
\hline \multicolumn{2}{|l|}{ Duration of type 2 diabetes mellitus } \\
\hline Less than 1 year & $17(7.3 \%)$ \\
\hline More than 1 year and up to 5 years & $85(36.6 \%)$ \\
\hline More than 5 years and up to 10 years & $67(28.9 \%)$ \\
\hline More than 10 years & $63(27.2 \%)$ \\
\hline \multicolumn{2}{|c|}{ Current type 2 diabetes mellitus treatment } \\
\hline One oral diabetes medication only & $111(47.8 \%)$ \\
\hline Two oral diabetes medication only & $68(29.3 \%)$ \\
\hline Three or more oral diabetes medication & $53(22.8 \%)$ \\
\hline
\end{tabular}




\section{Current Research in Diabetes \& Obesity Journal}

\begin{tabular}{|c|c|}
\hline \multicolumn{2}{|c|}{ Current HbA1c level } \\
\hline Below 53mmol/mol (Below 7\%) & $71(30.6 \%)$ \\
\hline Between 54mmol/mol and 64mmol/mol (Between 7.1\% and 8\%) & $51(22.0 \%)$ \\
\hline Between 65mmol/mol and 75mmol/mol (Between 8.1\% and 9\%) & $29(12.5 \%)$ \\
\hline Higher than 75mmol/mol (Higher than 9\%) & $11(4.7 \%)$ \\
\hline Don't know & $70(30.2 \%)$ \\
\hline
\end{tabular}

BMI: Body Mass Index; GCSE: General Certificate of Secondary Education; HbA1c: Glycated Hemoglobin; SD: Standard Deviation

aThe standard calculation formula: [Weight in Kilograms/(Height in meters $x$ Height in meters)] was used to calculate BMI

\section{DCE Results}

\section{Preferences in the overall sample}

The part-worth utility values from the logit regression and relative importance for the overall sample are presented in Table 3. The results of the overall analyses and all subsequent subanalyses supported the validity of the study design, with participants trading off on the levels of all attributes logically. A priori, it was expected that participants would prefer less gastrointestinal side effects, less frequent dosing, weight loss, greater percentage of patients at HbA1c goal, lower likelihood of pancreatitis, and less frequent hypoglycemia. Participants also indicated a preference towards a single-use pre-filled pen delivery system.

The relative importance of attributes were, in rank order, (1) type of delivery system (RI=19.8\%), (2) frequency of gastrointestinal side effects (RI=18.2\%), (3) dosing frequency (RI=17.7\%), (4) weight change (RI=15.6\%), (5) HbA1c change (RI=14.2\%), (6) frequency of pancreatitis (RI=12.3\%), and (7) frequency of hypoglycemia (RI=2.2\%).

Table 3: Part-worth utilities, relative importance, and rankings of attributes in overall sample.

\begin{tabular}{|c|c|c|c|c|c|c|}
\hline Attribute & Levels & $\begin{array}{l}\text { Part-Worth } \\
\text { Utility Estimate } \\
\text { (SE) }\end{array}$ & P-value ${ }^{a}$ & $\begin{array}{c}\text { Overall Part- } \\
\text { Worth Utility } \\
\text { Value }\end{array}$ & $\begin{array}{c}\text { Relative } \\
\text { Importance (\%) }\end{array}$ & Rank \\
\hline \multirow{2}{*}{$\begin{array}{l}\text { Type of delivery } \\
\text { system }\end{array}$} & $\begin{array}{l}\text { Single-use pre- } \\
\text { filled pen }\end{array}$ & $0.506(0.065)$ & $<0.0001$ & \multirow{2}{*}{1.01} & \multirow{2}{*}{$19.8 \%$} & \multirow{2}{*}{1} \\
\hline & $\begin{array}{c}\text { Multi-dose } \\
\text { prefilled pen }\end{array}$ & $-0.506(0.065)$ & $<0.0001$ & & & \\
\hline \multirow{2}{*}{$\begin{array}{l}\text { Frequency of } \\
\text { gastrointestinal } \\
\text { side effects }\end{array}$} & $\begin{array}{l}15.4 \% \text { experience } \\
\text { nausea in the } \\
\text { first } 18 \text { months of } \\
\text { treatment }\end{array}$ & $-0.464(0.050)$ & $<0.0001$ & \multirow{2}{*}{0.93} & \multirow{2}{*}{$18.2 \%$} & \multirow{2}{*}{2} \\
\hline & $\begin{array}{l}1.5 \% \text { experience } \\
\text { nausea in the } \\
\text { first } 18 \text { months of } \\
\text { treatment }\end{array}$ & $0.464(0.050)$ & $<0.0001$ & & & \\
\hline \multirow{2}{*}{ Dosing frequency } & Once a day & $-0.451(0.060)$ & $<0.0001$ & \multirow{2}{*}{0.90} & \multirow{2}{*}{$17.7 \%$} & \multirow{2}{*}{3} \\
\hline & Once a week & $0.451(0.060)$ & $<0.0001$ & & & \\
\hline \multirow{2}{*}{ Weight change } & $\begin{array}{c}\text { Weight gain of } \\
1.44 \mathrm{~kg} \text { within first } \\
12 \text { months }\end{array}$ & $-0.397(0.049)$ & $<0.0001$ & \multirow{2}{*}{0.79} & \multirow{2}{*}{$15.6 \%$} & \multirow{2}{*}{4} \\
\hline & $\begin{array}{c}\text { Weight loss of } \\
1.87 \mathrm{~kg} \text { within first } \\
12 \text { months }\end{array}$ & $0.397(0.049)$ & $<0.0001$ & & & \\
\hline \multirow{2}{*}{ HbA1c change } & $\begin{array}{c}30.9 \% \text { reach } \\
\text { HbA1c }<7 \% \\
\text { within first } \\
12 \text { months of } \\
\text { treatment }\end{array}$ & $-0.362(0.050)$ & $<0.0001$ & \multirow{2}{*}{0.72} & \multirow{2}{*}{$14.2 \%$} & \multirow{2}{*}{5} \\
\hline & $\begin{array}{c}53.2 \% \text { reach } \\
\text { HbA1c }<7 \% \\
\text { within first } \\
12 \text { months of } \\
\text { treatment }\end{array}$ & $0.362(0.050)$ & $<0.0001$ & & & \\
\hline
\end{tabular}




\section{Current Research in Diabetes \& Obesity Journal}

\begin{tabular}{|c|c|c|c|c|c|c|}
\hline \multirow{2}{*}{$\begin{array}{l}\text { Frequency of } \\
\text { pancreatitis }\end{array}$} & $\begin{array}{l}0.7 \% \text { experience } \\
\text { pancreatitis in the } \\
\text { first } 18 \text { months of } \\
\text { treatment }\end{array}$ & $-0.315(0.039)$ & $<0.0001$ & \multirow[b]{2}{*}{0.63} & \multirow[b]{2}{*}{$12.3 \%$} & \multirow[b]{2}{*}{6} \\
\hline & $\begin{array}{l}\text { No patients } \\
\text { experience } \\
\text { pancreatitis in the } \\
\text { first } 18 \text { months of } \\
\text { treatment }\end{array}$ & $0.315(0.039)$ & $<0.0001$ & & & \\
\hline \multirow{2}{*}{$\begin{array}{l}\text { Frequency of } \\
\text { hypoglycemia }\end{array}$} & $\begin{array}{l}8 \text { events in the } \\
\text { first } 12 \text { months of } \\
\text { treatment }\end{array}$ & $-0.057(0.031)$ & 0.0688 & \multirow{2}{*}{0.11} & \multirow{2}{*}{$2.2 \%$} & \multirow{2}{*}{7} \\
\hline & $\begin{array}{l}5 \text { events in the } \\
\text { first } 12 \text { months of } \\
\text { treatment }\end{array}$ & $0.057(0.031)$ & 0.0688 & & & \\
\hline
\end{tabular}

HbA1c: Glycated Hemoglobin; SE: Standard Error

ap-value represents whether the part-worth utility estimate differs significantly from 0 .

\section{Preferences by sex}

The preferences of participants were examined by sex (Figure 2). Among males, dosing frequency (RI=19.1\%) and frequency of gastrointestinal side effects $(R I=19.0 \%)$ were the most important attributes. Among females, type of delivery system $(\mathrm{RI}=25.6 \%)$ and weight change $(\mathrm{RI}=20.7 \%)$ were the most important attributes. Examining the part-worth utilities, for the weight attribute, females had a significantly stronger preference for weight loss and dis-preference for weight gain compared with males $(\mathrm{p}<0.05)$ (Figure 2).

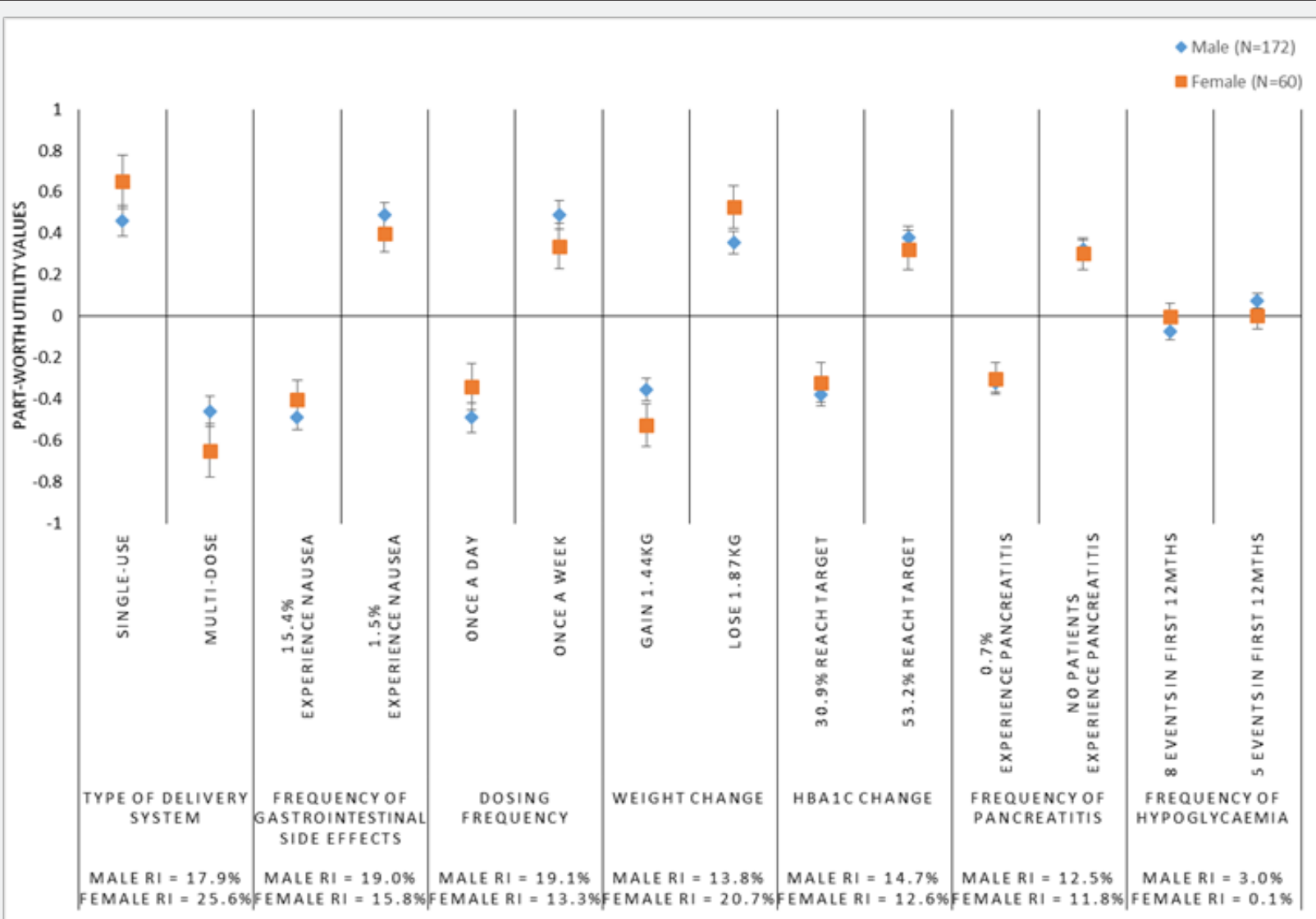

Figure 2: Attribute preference: by sex.

\section{Preferences by age group ( $<60$ years vs. $\geq 60$ years)}

Participant preferences were examined by age groups $<60$ years $(n=95)$ and $\geq 60$ years $(n=137)$ (Figure 3$)$. The preferences and relative importance of the attributes were fairly consistent across the two age groups with the exception of dosing frequency, which was significantly more important among older 
participants $(\mathrm{RI}=21.1 \%$; Rank=1) compared with the younger group (RI=12.5\%; Rank=6) $(\mathrm{p}<0.05)$. While both groups preferred less frequent, once a week dosing, this preference was significantly stronger among the older participants $(p<0.05)$.

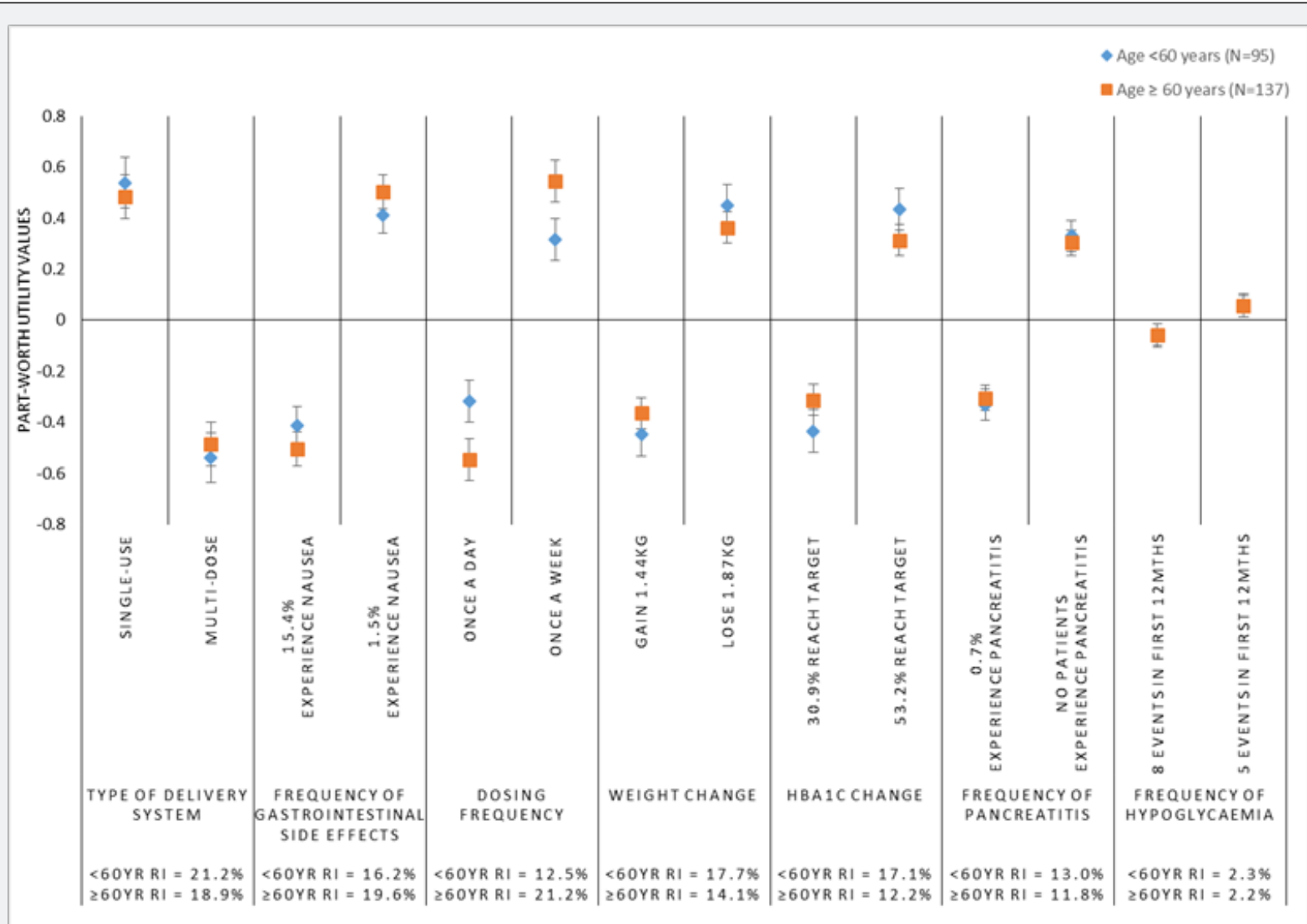

Figure 3: Attribute preference: by age group ( $<60$ years vs. $\geq 60$ years).

Preferences by duration of diabetes $\leq 5$ years vs. $>5$ years

The preferences of participants were also examined by duration of diabetes, comparing participants diagnosed with diabetes for five years or less $(n=102)$ to those diagnosed with diabetes for more than five years $(n=130)$ (Figure 4). There were no significant differences in the relative importance of the attributes across the groups, however, dosing frequency was the most important attribute to those diagnosed for $\leq 5$ years, while it ranked as the $5^{\text {th }}$ most important among patients diagnosed for more than 5 years. Further, patients who had been more recently diagnosed had significantly stronger preferences for once a week dosing $(\mathrm{p}<0.05)$.

\section{Willingness to self-inject medication for type 2 diabetes}

Prior to reviewing the attributes and levels, and completing the DCE, approximately one-third of participants (31.5\%) were "somewhat willing" or "very willing" to take a diabetes medication that required an injection for each dose, and about half (49.6\%) were "not willing" or "somewhat not willing." The remaining participants were "neutral" (18.5\%) and one participant did not respond to the question $(0.4 \%)$.

Following completion of the DCE, more than half (59.5\%) of participants in the overall sample were "somewhat willing" or "very willing" to take a medication represented by the dulaglutide profile compared to $31.9 \%$ for the medication represented by the insulin glargine (SoloSTAR $®$ ) profile. Only $23.3 \%$ were "not willing" or "somewhat not willing" to take the medication represented by the dulaglutide profile compared to $46.1 \%$ for the insulin glargine (SoloSTAR $®$ ) profile. $17.2 \%$ and $22.0 \%$ of participants were "neutral" towards the dulaglutide and insulin glargine (SoloSTAR $®$ ) profiles, respectively. The difference in willingness to take a medication represented by the dulaglutide profile compared to a medication represented by the insulin glargine (SoloSTAR®) profile was statistically significant $(\mathrm{p}<0.0001)$.

\section{Preference for dulaglutide vs. insulin glargine (SoloSTAR®) profiles}

As part of the DCE, participants were presented with profiles representing dulaglutide and insulin glargine (SoloSTAR $®$ ). In this direct comparison of medication profiles, $75 \% \quad(n=174)$ of participants preferred the profile representing dulaglutide 
compared to $25 \%(n=58)$ who preferred the profile representing insulin glargine (SoloSTAR $\AA)(p<0.0001)$. Among participants preferring the insulin glargine (SoloSTAR $囚$ ) profile, frequency of gastrointestinal (GI) side effects (RI=45.3\%) and frequency of pancreatitis $(\mathrm{RI}=26.5 \%)$ were the two most important attributes. In contrast, among those preferring the profile for dulaglutide, the type of delivery system $(\mathrm{RI}=24.5 \%)$ and the dosing frequency $(\mathrm{RI}=19.2 \%)$ were the most important.

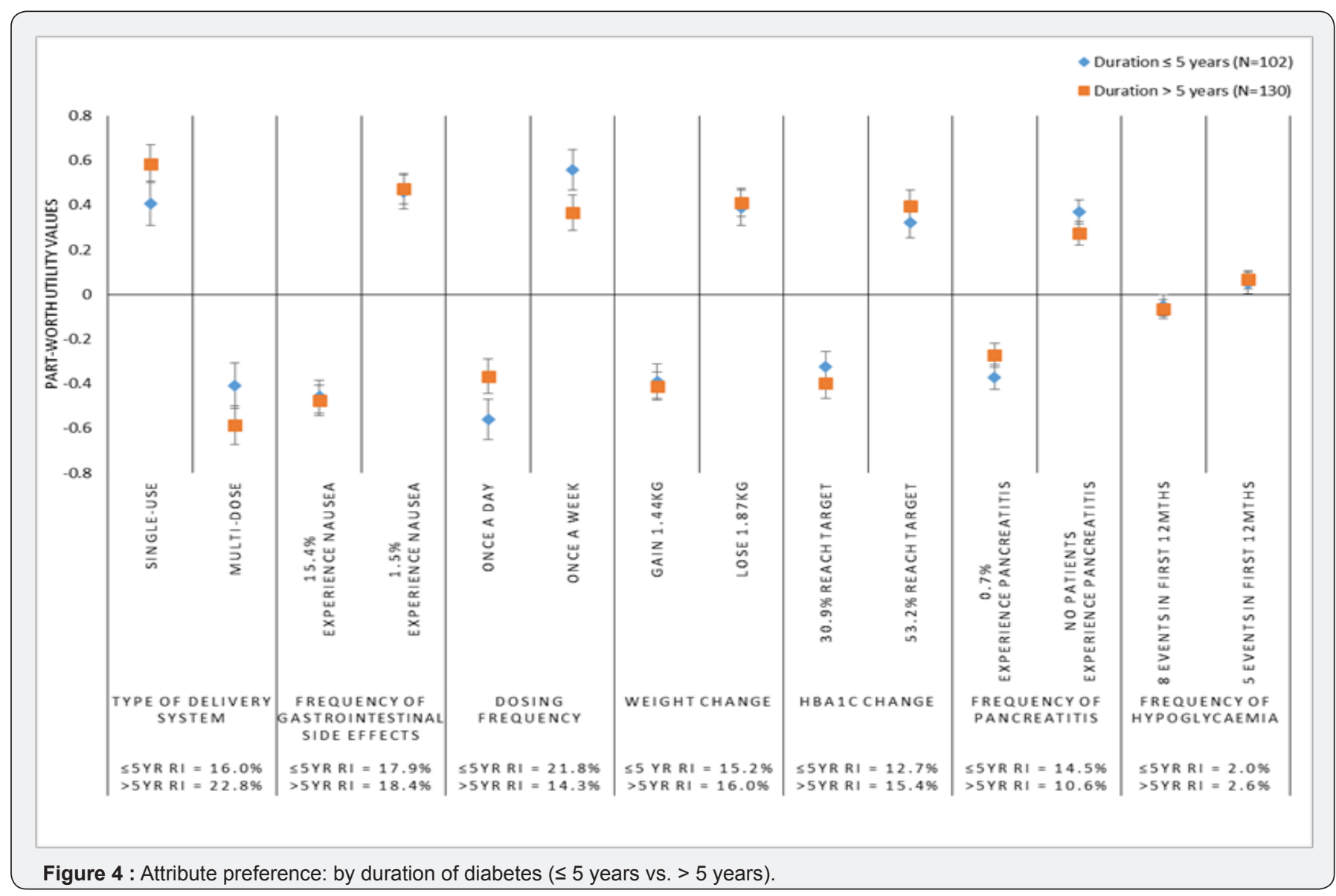

\section{Discussion}

In this DCE to determine patient preferences for the treatment features, efficacy, and side effects of dulaglutide $1.5 \mathrm{mg}$ and insulin glargine injectable treatments for type 2 diabetes, study participants indicated through their choices that type of delivery system, less frequent gastrointestinal side effects in the form of nausea, less frequent dosing, weight loss, a greater likelihood of reaching HbA1c goals of less than $7 \%$ within the first 12 months of treatment, and lower risk of pancreatitis were all important factors in their medication decisions (ie, RIs ranging from $10.2 \%-19.8 \%$ ). Subgroup analyses by sex, age, and duration of diabetes also showed similar trends.

In the context of this study, the frequency of hypoglycemia was less important compared to the other attributes, this was likely due to the fact that the overall frequency of hypoglycemia was relatively low and not highly differentiating across the profiles presented. Prior studies have reported a range of results on the importance of hypoglycemia with some finding that this attribute is rather unimportant $[7,8]$ and others finding that it is of greater relevance to patients $[3,4,6]$. Some of these differences may be explained by the way the attribute is defined in various studies, with greater importance logically being assigned to the attribute when it is characterized as more severe, more frequent, or highly differentiating between the presented medication profiles.

A strength of this study is that the attributes and levels that were included in the current study represented the observed characteristics of existing medications, thus informing us on preferences in a way that is clinically relevant. In addition, participants were not presented with product names, nor information about the class of medication, but rather were asked to state their preferences based solely on the characteristics of the medications presented. This provides a more direct estimate of the importance of each factor. In addition, it also limits bias, for example, from participants who may have specific fears or concerns about insulin products [15].

Several attributes included in the present study were similar to those examined in previous studies conducted in the United Kingdom [8] and Japan [7], which had study designs that were dictated by very specific within class medication 
comparisons of two GLP-1 RAs. In contrast, the current study examined patients' preferences for features of medications from a cross-class comparison and thus, included attributes that highlighted differences between the classes. In the prior studies, where the levels for overall efficacy, weight change, and frequency of hypoglycemia were very similar, the relative importance of convenience factors such as dosing frequency (RI: 41.6\%-44.1\%) and delivery system (RI: 26.3\%-35.5\%) were very important $[7,8]$. In the current study, these convenience factors were somewhat less important as patients considered the more pronounced differences in the levels for HbA1c change and weight change that are characteristic of the differences between GLP-1 RA and insulin glargine treatments. Across all of these studies, participants consistently considered side effects as important factors in their decisions, with each side effect typically accounting for $10 \%-15 \%$ of the relative importance. A prior study examining preferences for dosing frequency, efficacy (HbA1c control), nausea, and hypoglycemia based on profiles of GLP-1 RAs found that efficacy was most important (RI=39\%), followed by nausea $(\mathrm{RI}=30 \%)$, hypoglycemia $(\mathrm{RI}=17 \%)$, and then dosing schedule (RI=14\%) [10], notably the dosing schedule attribute in this particular study compared once daily versus twice daily injections. Prior work by Flood and colleagues [3] is also consistent with the current results, among the type 2 diabetes patients, dosing regimen, weight change, efficacy, and several side effects were all relevant to patient decisions in cross-class comparisons.

The results of the current study should be interpreted with consideration of the following limitations. First, the participants for this study were recruited by convenience sampling through newspaper advertisements. While participants were screened for study eligibility based on carefully designed, pre-specified criteria, participants' clinical status were solely based on selfreport and the extent to which this sample represents the general population of UK patients with diabetes is unclear. The participants were, however, interviewed in-person, and their current diagnostic status was verified through a review of evidence of their current diabetes medications. Second, although discrete choice experiments are a common methodology for examining preferences for attributes of a wide-range of products and services, it is uncertain the degree to which the reported preferences reflect the actual preferences of patients considering real-life medication decisions or how strongly these preferences might influence their medication-related behaviors or that of their prescribing physician. Third, the comparisons characterized only one medication and the corresponding device from each class of interest. Thus, it is unclear the extent to which the results may be generalizable across the full range of medications within each class; this may be an area for future research. Fourth, the attributes and levels were based on data from a single head-to-head clinical study. Fifth, as with all DCE studies, only a limited number of attributes could be included. Titration and the need for blood sugar monitoring were not included in the current study, though it is worth noting that had they been included, these attributes would likely have favored dulaglutide. Finally, as this study was conducted in the UK, cost was also not included as an attribute as most patients do not pay out-of-pocket for medications.

\section{Conclusion}

The current study suggests that in a specific comparison of key treatment features of a GLP-1RA (dulaglutide) and insulin glargine (SoloSTAR $囚$ ), patients consider a wide-range of factors which include efficacy, convenience, and side-effects. Clinicians should use their clinical judgement to make prescribing decisions for their patients; however, in situations where there is no clear clinically-indicated treatment choice, and patients' preferences become a consideration, then the evidence presented in this article can inform clinicians' decision-making process.

\section{Acknowledgement \\ Funding/Conflict of interest}

This study was funded by Eli Lilly and Company (Indianapolis, Indiana, USA). HLG is a full-time employee of Evidera. JLP was a full-time employee of Evidera at the time this work was performed and is currently a full-time employee of Eli Lilly and Company. KSB, VTT, KN, and SWH are full-time employees and minor shareholders of Eli Lilly and Company. The authors report no other conflicts of interest in this work.

All authors had full access to all of the data in this study and take complete responsibility for the integrity of the data and accuracy of the data analysis.

\section{Authorship}

All named authors meet the International Committee of Medical Journal Editors (ICMJE) criteria for authorship for this manuscript, take responsibility for the integrity of the work as a whole, and have given final approval to the version to be published.

\section{Medical Writing, Editorial, and Other Assistance}

Editorial assistance in the preparation of this manuscript was provided by Emily Sargent and Fritz Hamme of Evidera. Support for this assistance was provided by Eli Lilly and Company.

\section{Compliance with Ethics Guidelines}

All participants provided informed consent prior to participating in the study and the study protocol was approved by an independent ethical review board (Ethical \& Independent Review Services; Study number 16100-01; Approved August 21, 2016).

\section{Data Availability}

The datasets generated during and/or analyzed during the current study are not publicly available due to the terms of consent to which the participants agreed, but individual data requests will be considered by the study team. 


\section{Current Research in Diabetes \& Obesity Journal}

\section{Thanking Patient Participants}

The authors would like to thank the study participants for their time and efforts which made the study successful.

\section{References}

1. American Diabetes Association (2017) 8. Pharmacologic approaches to glycemic treatment. Diabetes Care 40(Suppl 1): S64-S74.

2. Inzucchi SE, Bergenstal RM, Buse JB, Diamant M, Nauck M, et al. (2015) Management of hyperglycemia in type 2 diabetes, 2015: a patientcentered approach: update to a position statement of the American Diabetes Association and the European Association for the Study of Diabetes. Diabetes Care 38(1): 140-149.

3. Flood EM, Bell KF, de la Cruz MC, Ginchereau Sowell FM (2017) Patient preferences for diabetes treatment attributes and drug classes. Curr Med Res Opin 33(2): 261-268.

4. Gelhorn HL, Stringer SM, Brooks A, Thompson C, Monz BU, et al. (2013) Preferences for medication attributes among patients with type 2 diabetes mellitus in the UK. Diabetes Obes Metab 15(9): 802-809.

5. Hauber AB, Tunceli K, Yang JC, Gantz I, Brodovicz KG, et al. (2015) A survey of patient preferences for oral antihyperglycemic therapy in patients with type 2 diabetes mellitus. Diabetes Ther 6(1): 75-84.

6. Muhlbacher A, Bethge S (2016) What matters in type 2 diabetes mellitus oral treatment? A discrete choice experiment to evaluate patient preferences. Eur J Health Econ 17(9): 1125-1140.

7. Gelhorn HL, Bacci ED, Poon JL, Boye KS, Suzuki S, et al. (2016) Evaluating preferences for profiles of glucagon-like peptide-1 receptor agonists among injection-naive type 2 diabetes patients in Japan. Patient Prefer Adherence 10: 1337-1348.
8. Gelhorn HL, Poon JL, Davies EW, Paczkowski R, Curtis SE, et al. (2015) Evaluating preferences for profiles of GLP-1 receptor agonists among injection-naive type 2 diabetes patients in the UK. Patient Prefer Adherence 9: 1611-1622.

9. Hauber AB, Nguyen H, Posner J, Kalsekar I, Ruggles J (2016) A discretechoice experiment to quantify patient preferences for frequency of glucagon-like peptide- 1 receptor agonist injections in the treatment of type 2 diabetes. Curr Med Res Opin 32(2): 251-262.

10. Polster M, Zanutto E, McDonald S, Conner C, Hammer M (2010) A comparison of preferences for two GLP-1 products--liraglutide and exenatide--for the treatment of type 2 diabetes. J Med Econ 13(4): 655661.

11. Giorgino F, Benroubi M, Sun JH, Zimmermann AG, Pechtner V (2015) Efficacy and safety of once-weekly Dulaglutide versus insulin glargine in patients with type 2 diabetes on metformin and glimepiride (AWARD-2). Diabetes Care. Dec 38(12): 2241-2249.

12. European Commission Public Health (2015) Trulicity 0.75 mg solution for injection in pre-filled pen. Trulicity $1.5 \mathrm{mg}$ solution for injection in pre-filled pen.

13. Lantus SoloStar (2015) Lantus 100 units/ml Solution for Injection in a Vial.

14. Orme BK (2010) Getting started with conjoint analysis: strategies for product design and pricing. Research Publishers, Chicago, USA.

15. Brod M, Kongso JH, Lessard S, Christensen TL (2009) Psychological insulin resistance: patient beliefs and implications for diabetes management. Qual Life Res 18(1): 23-32.

\section{Your next submission with Juniper Publishers will reach you the below assets}

- Quality Editorial service

- Swift Peer Review

- Reprints availability

- E-prints Service

- Manuscript Podcast for convenient understanding

- Global attainment for your research

- Manuscript accessibility in different formats

( Pdf, E-pub, Full Text, Audio)

- Unceasing customer service

Track the below URL for one-step submission https://juniperpublishers.com/online-submission.php 